\title{
Economy or austerity. Drivers of retrospective voting before and during the Great Recession.
}

\author{
Marco Giuliani $^{\mathrm{a}}$
}

${ }^{a}$ Department of Social and Political Sciences, Università degli studi di Milano, Milano, Italy

Dipartimento di Science sociali e politiche, Università degli studi di Milano,

Via Conservatorio 7, 20122 Milano (Italy),

marco.giuliani@unimi.it, Tel. +39.02.50321210

During the Great Recession, exceptionally harsh economic conditions were often countered by austerity policies that, according to many, further worsened and protracted the negative conjuncture. Both elements, the poor state of the economy and the contractionary manoeuvers, are supposed to reduce the electoral prospects for incumbents. In this article, we compare the relative explanatory powers of these two theories before and during the economic crisis. We demonstrate that in normal times citizens are fiscally responsible, whereas during the Great Recession, and under certain conditions, austerity policies systematically reduced the support for incumbents on top of the state of the economy. This happened when the burdens of the manoeuvers were shared by many, in more equal societies, when the country was constrained by external conditionalities, and when readjustments were mostly based on tax increases.

Keywords: Economic vote; Austerity; Great Recession; Electoral behaviour; conditionality; inequality 


\section{Introduction}

Political scientists and economists share a common concern regarding the relationship between the economic and the political arenas. The theory of economic voting postulates that voters evaluate the incumbent parties on the basis of their capacity to manage the economy. Citizens use this cognitive shortcut in order to decide if they should confirm or punish incumbents in the ballot. This theory has been extensively confirmed by numerous empirical analyses, and has proved to be adaptable with minor adjustments to normal and exceptional times (Dassonneville and Lewis-Beck, 2019a; Lewis-Beck and Lobo, 2017).

Other scholars, mostly economists, postulate a different mechanism. Adopting a typical rational choice perspective, they connect the fiscal policy choices of incumbents, i.e. their chosen combination of revenues and expenditures, to the voters' reaction.

"Under the assumption that public output enters positively into the utility functions of citizens, the expenditure by itself will secure support for the politician. The taxes, however, will reduce the disposable income of citizens, thereby affecting them negatively and reducing support for the politician" (Buchanan and Wagner, 1977: 100).

We name this perspective, which emphasizes the unpopularity of the reduction of the public deficit, the "theory of the electoral consequences of fiscal adjustments", in short the "theory of austerity vote". Also this approach has a long intellectual history, and has provided more fine-grained hypotheses for understanding what happened in the past and in the more recent period of the economic crisis.

Both perspectives resonate well with the empirical evidence provided by the qualitative literature investigating the Great Recession. The harsh economic conditions mobilized citizens against their governments, producing in certain areas of the world what has been dubbed an "electoral and government epidemics" (Bosco and Verney, 2016). At the same time, the austerity policies adopted by many executives, following the advice of international and supranational organizations such as the International Monetary Fund and the European Union, attracted their own 
share of criticisms, and triggered further dissatisfaction and contestation. From Zuccotti Park in New York to Syntagma Square in Athens, from the Austurvöllur in Reykjavík to the Puerta del Sol in Madrid, the protest took different forms, identified different targets, and had different electoral consequences also because of the specific combination of economic conditions and austerity policies peculiar to each national context.

Yet the two approaches are not equivalent, and what they observe are not simply two sides of the same coin. The economic vote theory focuses on outcomes: the state of the economy. The theory of fiscal adjustment focuses on outputs: the deliberate choices of incumbents. The former approach is based on sociotropic evaluations, at least in its version based on objective data, whereas the latter is micro-founded on individual utility functions. The former perspective relies on an indirect judgment on a valence issue such as the managerial capacity of incumbents; the latter one on a direct judgment on a positional issue such as the adoption of an expansionary versus a contractionary fiscal policy. Moreover, the policy choices of incumbents are not simply dictated by events or the actual state of the economy, so that there is no correlation between macroeconomic indices and the incumbents' policy choices. Faced by a similar crisis situation, policy-makers have reacted dissimilarly: forcing expansionary policies - consider the so-called Abenomics - or preferring a more austere approach - as happened in many European countries.

Using a dataset composed of electoral and economic data relative to 36 democratic countries that went to the polls for a general election 159 times between the years 2000 and 2015, we aim at comparing the prediction of the above introduced theories, detailing their utility and explanatory fit in ordinary and in exceptional times, before and during the Great Recession. We demonstrate that the theory of economic voting has a wider application, although it is usefully complemented by the approach focused on fiscal adjustments in the period of the Great Recession. Furthermore, our analysis suggests that tax hikes are more dangerous for incumbents than expenditure cuts, and that more equally distributed costs entail a more systematic electoral reaction. 
The article first introduces the main elements of the two theories of electoral behaviour, and contextualizes their empirical validity in face of the events of the Great Recession. This discussion helps us to put forward our main working hypothesis regarding the impact of austerity. Next, we identify three sets of factors that should fine-tune that impact, and advance some corollary hypotheses regarding their conditional effect. We then describe our dataset, and justify the operationalization of the variables and the choice of the model. Eventually we present the results of our analyses, and then discuss them also considering the distributional problems connected to bearing the costs of the Great Recession.

\section{Theory: Electoral behaviour, state of the economy, and fiscal adjustments}

The theory of economic voting is the most relevant example of a theory of voting behaviour that starts from a retrospective evaluation. Voters, instead of looking forwards at the correspondence between their preferences and the policies promised by different parties, typically in their electoral platforms, look backwards at what incumbents have accomplished (Key, 1966). Amongst the wide range of issues that they may have tackled, economic problems are consistently perceived as the most significant in different contexts and periods, and for this reason incumbents are primarily judged against their record in managing the state of the country's economy. According to this basic model, citizens do not need to be experts or thoroughly informed on the actual macro-economic figures in order to judge the economic conditions of their country (Fiorina, 1981). They form and continuously adjust their evaluation in many different ways, but mostly using some cognitive shortcuts and with a limited time horizon.

The logic of this economic retrospective judgment can be empirically modelled in two ways: using subjective individual judgements, or aggregated objective indices (Stegmaier, Lewis-Beck and Park, 2017). Using survey data, it is possible to check directly the respondents' evaluation of the incumbent's performance, thus tackling at its origin the perspective of the agent, and the causal mechanism at play. At the same time, there is the risk of falling into the trap of endogeneity and 
reverse causality, whenever respondents align their judgment to their voting behaviour, by rationalizing the former on the basis of the latter (Evans and Pickup, 2010). This problem is not present in the work of scholars employing clearly exogenous data, like the objective macroeconomic conditions of the unit of interest. And yet this approach risks falling in another methodological trap, the one regarding the ecological fallacy: deriving individual behaviours on the basis of aggregated association. Dassonneville and Lewis-Beck (2014: 390) convincingly demonstrate that this potential risk, together with its opposite, the fallacy of composition, is empirically misplaced. Thanks to the "macro refutation of the micrological fallacy, along with the micro refutation of the ecological fallacy, (...) with unparalleled confidence, we can assert that economic voting is real, and really matters".

Testing that political reaction during the Great Recession posed new problems (Lewis-Beck and Lobo, 2017). For the micro-subjective approach, there is the problem of restricted variance. In that tough period, everyone correctly perceived a deterioration of the national economy; however, it is impossible to attribute the variable support of incumbents to a constant like that shared assessment. For the macro-objective approach, the problem is that of correctly specifying the model. The results obtained by using aggregated data were originally instable, and models have been carefully fine-tuned since Powell and Whitten (1993) analysis to improve their robustness. It is now fairly common to check for clarity of responsibility issues (Dassonneville and Lewis-Beck, 2017; Silva and Whitten, 2017), as well as for other institutional and political confounding factors (Bengtsson, 2004).

However, the Great Recession raised further challenges that needed to be tackled to gain better understanding of retrospective behaviours in normal and extraordinary times. For example, the global character of the crisis suggests that voters probably used different external benchmarks to evaluate their own economy in that period (Kayser and Peress, 2016). Furthermore, scholars need to reflect carefully on the actual quantity triggering the economic vote, the absolute state of the 
economy rather than its trend, and reconcile short-term and long-term forces affecting political behaviours (Dassonneville and Lewis-Beck, 2019a).

The theory of the electoral consequences of fiscal adjustments starts from the utility functions of voters. The basic idea is that, all other things being equal, citizens appreciate governments that reduce their tax burden and expand their services, and disapprove those cabinets that increase taxes and reduce expenditures. Therefore, there would be an inherent pro-deficit bias in democratic politics (Buchanan and Wagner, 1977), whilst "large reductions of budget deficits (...would become) the kiss of death for the governments that implement them" (Alesina, Carloni and Lecce, 2013: 531). This baseline model brackets important issues, like, for example, partisan political preferences (Savage, 2019), trade-offs between revenues and outlays, the credibility of policy-makers (Alesina, Perotti and Tavares, 1998), external constraints (Hellwig, 2015), and longterm economic sustainability (Alesina and Passalacqua, 2017).

In an era that, well before the onset of the crisis, has been labelled of "permanent fiscal austerity" (Pierson, 2001), political scientists and welfare scholars have mostly underlined the institutional conditions for countering that inherent bias and avoid the blame for being fiscally responsible (Jensen and Mortensen, 2014). At the same time, other scholars, mostly economists, have directly challenged the idea that fiscal adjustments increase the probability of government turnover. Already in the 1990s, Alesina, Perotti and Tavares (1998) showed that cabinets that cut deficits of even more than 1.5 percentage points of GDP were not punished by voters. They also ruled out the possibility that their findings were the product of reverse causation: by looking at the executive popularity before and after the fiscal adjustment, they falsified the hypothesis that only strong governments were those that could afford to tackle those supposedly unpopular policies. They thus confirmed that 'electorates are fiscally 'responsible', that is, they do not like excessive deficits and understand that fiscal adjustments are sometimes necessary" (236).

If the null hypothesis represents the standard defence of the electoral feasibility of fiscal adjustments, more recent work takes some steps forward. Brender and Drazen (2008) argued that 
"voters are likely to punish rather than reward persistent budget deficits over the leader's term in office". i

\section{Conditional expectations: Great Recession and austerity voting}

One limitation of most of these, even recent, economic analyses is that they focus on data until 2008, leaving investigation of the most troublesome period of the Great Recession beyond their scope conditions. The whole idea of implementing austerity policies, often perceived as dictated by external non-elected bureaucrats, has recently become less appealing. After a brief period of expansionary reaction to the crisis (Blyth, 2013; Raess and Pontusson, 2015), fiscal contraction has become an important element in the punishment of governments, as Talving (2017) demonstrates using survey data. Governments can even be excused for not being able to maintain a healthy growth when the entire world economy is collapsing, but they cannot further put the costs of the recovery on the shoulders of their voters. According to Alonso and Ruiz-Rufino (2018), in the Eurozone, and especially in countries subject to the external supervision of the Troika, the blame for trying to be fiscally responsible extended well beyond the incumbents, incurring the same electoral fate for all the mainstream parties.

Whereas in normal times, economic policies typically produce winners and losers, and there are usually minor fluctuations between expansionary and contractionary manoeuvres, the response to the Great Recession required a series of large adjustments, creating mostly, if not only, losers. Everyone had something to lose in such situations of fiscal restraint. Furthermore, whereas in normal times governments can better exploit political-economic cycles, the degrees of freedom for such opportunities were reduced during the Great Recession by the same downward dynamics of the economy, as well as by the external constraints of the international community. Finally, after the onset of the crisis, the way in which governments chose to react to the downturn of the economy came to the forefront of public attention. Incumbents were judged not only on what they had 
delivered, according to the standard economic vote theory, but also on how they had shared the burden of the intervention, i.e. on their austerity policies. Thus:

Hp. 1: Besides the state of the economy, fiscal contraction decreased the electoral prospects of incumbents only after the onset of the crisis.

This average expected effect may also depend on a series of conditioning factors that should be considered in order to evaluate the potential for systematic punishment of incumbents due to their fiscal strategies. We identify three different sets of conditioning factors: social, institutional, and policy-related.

Inequality represents the first conditioning social influence. Tests of the economic vote theory have often underlined that electoral behaviours are triggered more by sociotropic than by egotropic considerations. This should apply also to the austerity vote. If the burden of restrictive policies is placed only on specific social groups, which, all other things being equal, is more likely in less equal societies, incumbents should be rewarded by some and punished by others. This would translate into a non-significant coefficient for austerity in our model. This is exactly what happened before 2008, whereas the Great Recession increased the range of the negatively affected policy takers, so that most, if not all, could claim to have lost something.

Whereas a certain degree of inequality and class conflict is inherent in any policy altering revenues and expenditures (Franko, Tolbert and Witko, 2013), it is clear that economies with greater imbalances between the wealthy and the poor can more easily transfer the costs of fiscal consolidation onto some section of society. Conversely, economies that are more egalitarian tend to share those costs, so that when they become sizable enough, they translate into a systematic electoral loss for incumbents. ${ }^{\text {ii }}$ In other terms:

Hp. 2: The impact of austerity on voting behavior was higher in more equal societies.

A second, institutional, element concerns the issue of external conditionalities. One political problem with many austerity policies, apart from their dubious efficacy, was that they were externally imposed: by the global markets, the International Monetary Fund, or by the European 
Union. Contrary to those who argued that the multilevel structure of governance, by blurring the responsibilities, watered down the economic vote, some authors have contended that the inability to protect the national interest and sovereignty reinforced, rather than diminished, the dissatisfaction with incumbents (Armingeon and Guthmann, 2014; Giuliani, 2019).

A fortiori this should apply also to austerity votes, since externally imposed restrictive policies are felt to betray the accountability of incumbents to domestic preferences. The clearest example of this type of exogenous constraint is represented by the policy conditionalities enforced by the IMF on countries borrowing from that international organization. There should thus be a multiplicative effect of the blame when incumbents introduce austerity policies to comply with such an external institutional restriction.

Hp. 3: The impact of austerity on voting behavior was higher where (and when) those policies were dictated by the International Monetary Fund.

Finally, our last conditioning dynamic has to do with the policy composition of the economic manoeuvre. Austerity policies may be predominantly tax-based rather than expenditurebased. In the former case, fiscal surpluses are mostly obtained through increased revenues, while in the latter they are so mostly through service cuts. Admittedly, this is a very rough distinction, and the electoral effects of those choices may further depend on the specific structure of those taxes and cuts, on the targeted social groups, and on the political leaning of the incumbents adopting them. However, there are dynamics that may transcend those more fine-grained factors.

All other things being equal, service and welfare cuts can be more easily tailored to specific sectors of society, whereas tax increases affect comparatively wider portions of society. The former may be extremely divisive, because they disproportionately affect some groups more than others. On the same grounds as we cited regarding inequality, they should not produce the same systematic punishment of incumbents as produced by tax hikes. Increasing the revenues, especially if intended to substantially tackle a country's deficit, produces an all-losers situation. Acknowledging that the marginal imposition on some groups is heavier than on others does not alter the common 
punishment of the incumbents' choices. In fact, Alesina, Favero and Giavazzi (2019) suggest that "cases (of fiscal consolidation) in which the expenditure share of the adjustment was higher were associated with less frequent changes in government, (whereas) tax-based adjustments make it more difficult for incumbent governments to be reappointed" (178).

Hp. 4: Austerity taxation triggered the punishment of incumbents more than cuts in spending did.

\section{Data, operationalization, and method}

The crisis affected the whole planet at various levels, and yet the more advanced economies have been upset more than the emerging markets. This is a first reason for concentrating only on wellestablished economies, members of the Organization for Economic Cooperation and Development (OECD), and/or the European Union (EU). A second reason is that amongst that group of countries it is more probable to find consolidated democracies, the only type of regime for which elections and the retrospective evaluation of incumbents have a genuine meaning. A third selection criterion is more pragmatic, and it has to do with the availability of homogeneous economic data, especially insofar as government finances are concerned.

The overlap of these three criteria left us with 36 countries. Most of them are located in Europe, and yet the sample includes also countries in North America, Asia and the Antipodes. ${ }^{\text {iii }}$ The period considered was the one between 2000 and 2015, symmetrically divided before and after the onset of the crisis. We preferred not to further extend that period in the past to preserve that symmetry, and avoid including potential unnecessary confounding events. Although several economies technically exited swiftly from the Great Recession, some have not yet fully recovered. Moreover, the global memory of that period still survives, together with its enduring political consequences. During those years, in our sample countries, there were 159 general elections: 79 before 2008, and another 80 afterwards. ${ }^{\text {iv }}$ 
Our dependent variable was incumbent support measured as the cumulative percentage of votes received by all government parties. We preferred to use that aggregate measure instead of simply the support for the prime minister's party because it better represents the mood in favour or against the government. Furthermore, in so doing, we avoided considering a simple transfer of votes amongst coalition partners as an increase or decrease of support for the government. Whereas in the elections considered in our models for the years between 2000 and 2007 incumbents lost on average 3.5 percentage points, in the $2008-2015$ period they lost on average 7.8 points against the previous election.

We used the unemployment rate in the four quarters preceding the election to measure the state of the economy. Unemployment has the longest history as an index for retrospective studies (Lewis-Beck and Stegmaier, 2013; Nannestad and Paldam, 1994), and it is the most direct measure of the grief produced by the Great Recession. Growth displays in that same period some irregular up-and-downs, and we included it mostly as a further control, to replicate as close as possible standard models of economic voting.

As measure of austerity we employed the change in the cyclically adjusted primary balance (Alesina, Favero and Giavazzi, 2019; Alesina and Giavazzi, 2013; Talving, 2017). "Essentially, the measure captures changes in expenditures and revenues that cannot be explained by rising claims for social benefits at constant benefits generosity and falling revenues at constant tax rates" (Raess and Pontusson, 2015: 6), thus focusing on "purposeful changes in spending and taxation" (Alesina, Perotti and Tavares, 1998: 214). We are aware of the ongoing debate in the field arguing in favour of the so-called narrative approach (Devries et al., 2011), relying on budget plans and documentation from national and international authorities. Apart from the difficulties in adapting this method to our temporal horizon, there is evidence of consistent non-random "consolidation promise gaps" (Gupta et al., 2018), i.e. differences between planned and realized fiscal adjustments that could affect the interpretation of our results should we adopt that alternative approach. 
Our index relied on estimates of the potential output of each economy. Its comparison thus required a homogeneous source of data, which induced us to use the IMF Fiscal Monitor dataset, which has the widest possible coverage of the advanced democratic economies chosen for this study. We adapted the annual measures to the timing of the election, using the same weighted average adopted for the economic variables described in the online appendix. Positive values of our austerity index meant an increase of the adjusted primary balance, i.e. contractionary policies involving a voluntary increase in taxation or a cut in spending, or both. Contrary to some common suppositions, there has been a great variation amongst austerity policies both before and after the onset of the Great Recession, as it is demonstrated in the descriptive part of the online appendix.

In regard to our conditioning factors, we measured inequality using the Gini index computed on income distribution by the World Bank, the source that offered the widest cross-country and longitudinal coverage of our sample. Nonetheless, we had to resort to the multiple imputation strategy described in the online appendix to reduce the impact of missing values. The IMF conditionality was measured as a dummy variable assuming the value of 1 in those country-years in which there was a support agreement with the international organization. Finally, we computed an index representing the composition of the fiscal policy by subtracting the increase in the share of expenditures on GDP from the increase in the share of taxation. This index assumed a null value when a certain increase/decrease in revenues was balanced by the same increase/decrease in spending. Positive values of the index correspond to a tax-based austerity, whereas negative values are associated with policies based on spending cuts.

The aggregated approach to retrospective voting usually requires a set of control variables. We accordingly included a dummy variable for coalition governments, for issues of clarity of responsibility (Silva and Whitten, 2017), as well as to absorb the inflation of votes in the case of multiple parties composing the executive. We further added the effective number of electoral parties to capture the availability of alternatives to incumbents (Rowe, 2015), and the change in the 
level of turnout against the preceding general election to hold constant the effect of the level of mobilization on vote choice (Weschle, 2014).

Because of the cross-section time-series structure of our data, with more units than points in time (36 countries for a number of elections varying overall between 3 and 8), we used a panel regression with random effects. Our coefficients thus reflect mostly a cross-country effect, which is the same as saying that there was some common understanding of the depth of the crisis, and not just a relative evaluation against each own recent past. In fact, most of the variation was actually between-country, and a Hausman test on the complete models confirmed that random effects are to be preferred against using fixed effects.

The latter would have implicitly modified our hypotheses into an investigation of the effects of changes in austerity policies on incumbents support, which is only part of our description of the correlates of different amounts of austerity (Neumayer and Plümper, 2017). In accordance with standard practices (Angrist and Pischke, 2009), we introduced a lagged dependent variable to account for time-varying unobserved heterogeneity and to further control for the size of each incumbent executive, and for unmodelled specificities of each electoral context.

Finally, we adopted a split sample research design that made the comparison much clearer, though interacting our covariates with a crisis dummy confirmed the same findings. Our methodological choices and alternative models are further discussed in the online appendix.

\section{Austerity over and above the economy?}

We started by regressing the support for incumbents on the state of the economy before the Great Recession, and then we added our austerity measure. Next, we replicated the same two steps for the period after the onset of the crisis. The results of these first four analyses are presented in Table 1.

The first model empirically translated the standard theory of retrospective economic voting. The coefficients for unemployment and growth presented the expected opposite signs, although 
only the former was statistically significant. For each point of the rate of unemployment incumbents lost slightly more than 1 percent of their votes.

Cursory inspection of the control variables shows that the coefficient for the incumbents' vote in the previous election indicates a non-marginal degree of persistence of the government support. The dummy for coalition has the expected positive sign, with the lack of clarity partially restoring a fraction of the lost votes; however, the coefficient is not statistically significant. The presence of many electoral alternatives, represented by the proxy for the effective number of parties, systematically reduces the incumbents' chances of being confirmed in the ballot. The sign of the coefficient for the change in the turnout levels is coherent with the mobilization hypothesis, with unsatisfied citizens using their votes to favour some alternation in power.

Model 2 added to the previous equation the government's austerity policies, measured as an increase in the cyclically adjusted primary balance. The coefficient for austerity was statistically insignificant, mirroring the conclusion of Alesina, Perotti and Tavares (1998) regarding fiscally responsible citizens that do not punish governments that cut deficits. Although this result does not support the idea that the electorate actually rewards the supposedly necessary fiscal adjustments, it certainly disconfirms the basic rational choice assumption according to which the electorate always rewards expansionary policies. Alternatively, endogenizing that same assumption, executives act strategically by avoiding approval of any fiscal consolidation shortly before the ballot (Hübscher and Sattler, 2017), thus reducing the variation in the pre-electoral manoeuvres so that it is impossible to register any significant impact of that variable.

This model had a slightly better fit than the first equation, although the somewhat higher explained variance may have been a statistical artifact resulting from having one more variable in the right-hand side of the equation. This regression only confirms the robustness of economic voting, without showing any additional explanatory contribution on behalf of the austerity variable. Viewed from a different perspective, this lack of statistical significance is grist to the mill of those who counterintuitively argue that fiscal rigor is not as unpopular as generally thought, so that 
policy-makers should be less reluctant to introduce the required retrenchment policies (Alesina, Favero and Giavazzi, 2019; Alesina and Passalacqua, 2017; Brender and Drazen, 2008).

***Table 1 approximately here

Are the results for the period of the Great Recession similar to those that we have presented for normal times? Models 3 and 4 replicated the previous two regressions, and immediately apparent are some interesting differences.

First, the theory of economic voting is confirmed even in turbulent times, substantiating what has already been shown by other scholars using partially different samples of countries, sets of covariates, data sources, and types of model (e.g. (Dassonneville and Lewis-Beck, 2014; LewisBeck and Lobo, 2017). From a cross-country perspective, the absolute level of unemployment continues to impact robustly on the electoral performances of incumbents, and it is further complemented in both models by growth, thus confirming the political centrality of the economy in those troubled years.

Secondly, on adding austerity to the equation, also the theory on the electoral consequences of fiscal adjustments seems to be confirmed in the hard times of the Great Recession. In model 4, unemployment and growth kept their systematic effect, but, on top of the economic vote, for each point of fiscal consolidation incumbents lost almost 1.3 points in the ballots. In our sample, the number of countries that, summing up all the annual structural adjustments, had an overall fiscal contraction more than doubled in 2008-2015 compared to the previous period. The overall average of those sequences before the crisis was expansionary (-1.3 in the structural primary balance), whereas after the onset of the recession the same measure registered a contractionary positive value of 0.8 , with cycles of austerity packages peaking above a 10-point adjustment in countries like Greece, Portugal, Spain, and Iceland. ${ }^{v}$ Austerity clearly came to the forefront in that period, both 
because of its extent and magnitude, and because of its frequent perception as the wrong cure for the ongoing disease (Blyth, 2013).

Interestingly, our models fit the crisis period better than the one before 2008, with a parallel increase of the explained variance in both types of equations, and with an overall R-squared reaching $60 \%$ for the last full model. As regards the control variables, they mostly behave as before the crisis, with the exception of the trend in turnout, whose coefficient is now positive: the more people voted, the better the incumbents' results, meaning that some of the dissatisfaction regarding their managerial capacities was funnelled into abstention (Giuliani and Massari, 2018).

Having verified our first hypothesis, it is time to fine-tune it by checking if also some of our conditional expectations are confirmed. Their nature recommends the direct plotting of the marginal effects of austerity at varying degrees of the interacting factors, which is what we do in figure 1 by starting with inequality and then moving to the IMF conditionality and to the different balance between expenditure cuts and tax increases in the composition of fiscal policies. ${ }^{\mathrm{vi}}$ Admittedly, the interactive effect is weak, and the inevitably small number of observations - even this protracted crisis was limited in time - widens the $95 \%$ confidence intervals. Nonetheless, in each of our plots, the impact of austerity is significantly different from zero on one of the two extremes of the conditional variable, and not on the other, confirming the sizeable relevance of the interaction.

In regard to the conditioning role of inequality, our hypothesis was that austerity policies exerted their negative electoral impact mostly in less unequal societies, where the fraction of policytakers affected by those fiscal decisions can be bigger. The upper panel of figure 1 corroborates this expectation. For more than half of the cases in our sample, fiscal consolidation has a systematic negative impact on the electoral prospects of incumbents. The absolute magnitude of that impact diminishes at increasing levels of inequality, until it cannot be distinguished from zero when the Gini index exceeds approximately the value of 32 . We can thus confirm that income imbalances counterintuitively moderate the magnitude of the electoral impact of austerity policies, which has 
nothing to do with the potential direct losses due to inequality in itself (Dassonneville and LewisBeck, 2019b).

*** Figure 1 approximately here

The second conditioning factor has to do with the constraints imposed on sovereign fiscal choices associated with the recovery programs offered by the Monetary Fund. Scholars testing the impact of those external conditionalities using individual (survey or experimental) data have obtained mixed results (Kosmidis, 2018; Ruiz-Rufino and Alonso, 2017; Talving, 2017). In the mid panel of figure 1, we replicated those tests using objective aggregate data and interacting austerity with conditionality. The marginal effects suggest that citizens find particularly hateful the external imposition of blood and tears fiscal adjustments, and thus punish their incumbents for having produced that state of affairs. The point estimate for non-supported countries is still slightly negative, but for them the standard $95 \%$ confidence intervals implies a null effect of fiscal policies on electoral behaviors. Typically, austerity and IMF intervention went hand in hand, with the harshest policies that have been introduced in countries that had abdicated their fiscal sovereignty to international organizations.

Finally, the bottom panel of figure 1 explores the idea that only certain types of austerity program give the kiss of death to incumbents (Alesina and Giavazzi, 2013). The interaction had to exclude two extreme elections, i.e. those in Estonia and Ireland in 2011, since the indexes of the relative composition of their fiscal policies were respectively two and three times smaller/higher than the most proximate case on the opposite sides of the scale. The plot of the marginal effects confirms that manoeuvres centered around expenditures cuts do not suffer from the same electoral side effects as those grounded in tax increases, and the more austerity exacts a toll directly on citizens' pockets, the more it is risky for those in government. ${ }^{\text {vii }}$ These provisional results, further corroborated by some robustness checks in the online appendix, are coherent with the normative 
and empirical contention by Alesina, Favero and Giavazzi (2019: chapter 10) that tax-based adjustments are both politically and economically ineffective.

\section{Discussion}

Austerity, as a concept, has a long tradition in the history of political and economic thought. Whereas discussion on its moral flavour was predominant at its origin, it was not until modern times that scholars like Adam Smith and Max Weber "introduced their readers to a world in which a select few, in possession of virtue and economic reason, adopted austere ways of life and were amply rewarded later. In contrast, Karl Marx and Thorstein Veblen conjured up a world in which there was nothing virtuous or rational about abstinence. Above all, in their view, the people doing the abstaining and those reaping the benefits were members of different groups" (Schui, 2014: 50).

To cut a longer story (Blyth, 2013) short, that contrast is still present in contemporary economic thought and practices. While Alesina, Favero and Giavazzi argue that "austerity is almost always the correction of past mistakes" and that "expansionary austerity" is indeed possible (2019: 194,196), Varoufakis dubs the austerity packages imposed on Greece as "fiscal waterboarding" (2018: 29). Since the onset of the Great Recession, the IMF itself seems to have at least partially changed its stance regarding the quantity and timing of the fiscal consolidation it imposed on the economies in crisis (Clift, 2018).

In this study, we have demonstrated that, under certain conditions, those policies reduced the electoral support for incumbents besides what the actual state of the economy already eroded. Our evidence, based on aggregated objective indicators, matches what others have shown using individual data or qualitative reconstructions (Bosco and Verney, 2016; Talving, 2017), and also agrees with those scholars pointing at the disturbing effect of having sacrifices imposed by outside international organizations (Armingeon and Guthmann, 2014).

Nevertheless, some previous studies maintained that austerity policies are not politically so detrimental (Alesina, Favero and Giavazzi, 2019; Alesina and Giavazzi, 2013; Brender and Drazen, 
2008). How can we reconcile their null results with our more sceptical view? A short answer could be that those studies watered down a relationship specifically triggered by the economic crisis by covering a longer time frame which only marginally overlapped with the Great Recession. Our Table 1 already revealed that before the onset of the crisis we did not observe the same depressing effect of fiscal consolidation on the electoral chances of incumbents. At that time, because of the relatively smaller size of the adjustments, as well as because of the shorter sequences and minor parallel diffusion of those contractionary manoeuvres, the theory of economic voting sufficed to explain the dynamics of political behaviours.

A second reason is that, whereas we explain the electoral success of incumbents, those studies typically checked the impact of austerity on government turnover, variously defined. ${ }^{\text {vii }}$ The difference is not only an issue of model specification. An electoral defeat does not automatically translate into a government change, and even the success of the incumbents is not a guarantee of confirmation in power. Apart from the purest types of Westminster systems, the appointment of a cabinet is very much an issue of arithmetic and political feasibility of alternative coalitions (Laver and Benoit, 2015). Thus, as Alesina and colleagues acknowledge (2019: 181), "reelection of governments (...) is a highly complex matter with many moving parts and many factors in place. As a result, isolating the role of fiscal adjustments in any statistical analysis may be difficult".

Looking at electoral results is much more straightforward and instructive, not least because it relies on a direct relationship between retrospective evaluation (of the economy and/or past policies) and citizens' behaviour, and avoids including unnecessary confounding factors. During the Great Recession, the gap between the results obtained by using the two different dependent variables increased because of the volatility of voters in regard to non-mainstream radical parties. Since the latter have been typically non-viable partners in coalitions, their electoral successes did not translate consistently in government turnovers, further justifying the mismatch between the two types of model. 
Thirdly, if austerity aims at competing with the state of the economy for the role of driver of electoral behaviours, we should again consider the issue of egotropic versus sociotropic perspectives that occupied the debate within the theory of economic voting. As with the latter, the two approaches do not need to be in any type of contradiction. Citizens could oppose hard austerity policies even without being directly affected by the specific tax increases or service cuts planned in those manoeuvres. Yet it is evident that austerity policies have an innate redistributive problem, as we underlined at the beginning of this section by citing Marx and Veblen.

The results of our conditional models call for a further in-depth analysis of the differentiating factors that magnify or moderate the electoral punishment of similar fiscal readjustments. In this regard, the statistical power of some of our models was limited by the number of observations and by some missing fiscal information. Nonetheless they all tell an interesting and different story. Equality and inequality are similarly distributed in countries assisted or not by the IMF, and the Gini index is not related to the tax-expenditure composition of fiscal policies either. Tax-based manoeuvres are admittedly typical of countries subject to lending agreements, but are still much more frequent than those $10 \%$ of our observations conditioned by the IMF.

By enlarging the share of those who suffered from the state of the economy and from the policies to counter that state of affairs, the Great Recession has probably reduced the gap between sociotropic and egotropic considerations. Yet it has also enlarged the one between output and outcome, with severe fiscal restraints and responsibilities not matched by a sufficiently swift economic recovery. Normatively speaking, the good news for democracy, and for the theory of political representation, is that, especially in equal societies, policy-makers have several incentives for being responsive to their principals. The bad news is that the Great Recession has eroded the traditional basis of democratic cohabitation beyond the usual alternation in government, with consequences that persist well after the end of the economic emergency. For this reason, further investigation of what happened in the extraordinary years of the Great Recession is still important: because they may become the new ordinary times. 


\section{Acknowledgement}

I would like to thank Michele Santoni, for introducing me to the debate around austerity amongst economists, and the three anonymous referees of the journal for their useful comments.

\section{Funding}

This work was supported by the Italian Ministero dell'Istruzione, dell'Università e della Ricerca: [Grant Number PRIN 2015P7RCL5]. 


\section{References}

Alesina, Alberto, Dorian Carloni and Giampaolo Lecce (2013) The Electoral Consequences of Large Fiscal Adjustments. In Alberto Alesina and Francesco Giavazzi (eds) Fiscal Policy after the Financial Crisis. Chicago: University of Chicago Press, 531-570.

Alesina, Alberto, Carlo Favero and Francesco Giavazzi (2019) Austerity : When It Works and When It Does Not. Princeton, NJ: Princeton University Press.

Alesina, Alberto and Francesco Giavazzi (2013) Fiscal Policy after the Financial Crisis. Chicago ; London: The University of Chicago Press.

Alesina, Alberto and Andrea Passalacqua (2017) The Political Economy of Government Debt. In John Taylor and Harald Uhlig (eds) Handbook of Macroeconomics (Vol. 2B). Amsterdam: Elsevier, 2599-2651.

Alesina, Alberto, Roberto Perotti and José Tavares (1998) The Political Economy of Fiscal Adjustments. Brookings Papers on Economic Activity (1): 197-266.

Alonso, Sonia and Rubén Ruiz-Rufino (2018) The Costs of Responsibility for the Political Establishment of the Eurozone (1999-2015). Party Politics

Angrist, Joshua David and Jörn-Steffen Pischke (2009) Mostly Harmless Econometrics : An Empiricist's Companion. Princeton: Princeton University Press.

Armingeon, Klaus and Kai Guthmann (2014) Democracy in Crisis? The Declining Support for National Democracy in European Countries, 2007-2011. European Journal of Political Research 53(3): 423-442.

Bellucci, Paolo (2014) The Political Consequences of Blame Attribution for the Economic Crisis in the 2013 Italian National Election. Journal of Elections, Public Opinion and Parties 24(2): 243-263.

Bengtsson, Åsa (2004) Economic Voting: The Effect of Political Context, Volatility and Turnout on Voters' Assignment of Responsibility. European Journal of Political Research 43(5): 749767.

Blyth, Mark (2013) Austerity: The History of a Dangerous Idea. Oxford ; New York: Oxford University Press.

Bosco, Anna and Susannah Verney (2016) From Electoral Epidemic to Government Epidemic: The Next Level of the Crisis in Southern Europe. South European Society and Politics 21(4): 383-406.

Brender, Adi and Allan Drazen (2008) How Do Budget Deficits and Economic Growth Affect Reelection Prospects? Evidence from a Large Panel of Countries. American Economic Review 98(5): 2203-2220.

Buchanan, James M. and Richard E. Wagner (1977) Democracy in Deficit. The Political Legacy of Lord Keynes. New York: Academic Press.

Clift, Ben (2018) The Imf and the Politics of Austerity in the Wake of the Global Financial Crisis (First edition. ed.). Oxford, United Kingdom: Oxford University Press.

Dassonneville, Ruth and Michael S. Lewis-Beck (2014) Macroeconomics, Economic Crisis and Electoral Outcomes: A National European Pool. Acta Politica 49(4): 372-394.

Dassonneville, Ruth and Michael S. Lewis-Beck (2017) Rules, Institutions and the Economic Vote: Clarifying Clarity of Responsibility. West European Politics 40(3): 534-559.

Dassonneville, Ruth and Michael S. Lewis-Beck (2019a) A Changing Economic Vote in Western Europe? Long-Term Vs. Short-Term Forces. European Political Science Review 11(1): 91108.

Dassonneville, Ruth and Michael S. Lewis-Beck (2019b) Inequality and Party Support: Positional Economic Voting or a New Dimension of Valence? Regional Studies: 1-10.

De Giorgi, Elisabetta and José Santana-Pereira (2016) The 2015 Portuguese Legislative Election: Widening the Coalitional Space and Bringing the Extreme Left In. South European Society and Politics 21(4): 451-468. 
Devries, Pete, Daniel Leigh, Jaime Guajardo and Andrea Pescatori (2011). A New Action-Based Dataset of Fiscal Consolidation. https://www.imf.org/ /media/Websites/IMF/imported-fulltext-pdf/external/pubs/ft/wp/2011/_wp11128.ashx

Evans, Geoffrey and Mark Pickup (2010) Reversing the Causal Arrow: The Political Conditioning of Economic Perceptions in the 2000-2004 U.S. Presidential Election Cycle. The Journal of Politics 72(4): 1236-1251.

Fiorina, Morris P. (1981) Retrospective Voting in American National Elections. New Haven: Yale University Press.

Franko, William, Caroline J. Tolbert and Christopher Witko (2013) Inequality, Self-Interest, and Public Support for "Robin Hood” Tax Policies. Political Research Quarterly 66(4): 923937.

Giuliani, Marco (2019) Economic Vote and Globalization before and During the Great Recession. Journal of Elections, Public Opinion and Parties: 1-20.

Giuliani, Marco and Sergio A. Massari (2018) It's the Economy, Stupid : Votare in Tempo Di Crisi. Bologna: Il Mulino.

Gupta, Sanjeev, João T. Jalles, Carlos Mulas-Granados and Michela Schena (2018) Planned Fiscal Adjustments: Do Governments Fulfil Their Commitments? European Union Politics 19(3): 383-407.

Hellwig, Timothy (2015) Globalization and Mass Politics : Retaining the Room to Maneuver. New York: Cambridge University Press.

Hübscher, Evelyne and Thomas Sattler (2017) Fiscal Consolidation under Electoral Risk. European Journal of Political Research 56(1): 151-168.

Jensen, Carsten and Peter B. Mortensen (2014) Government Responses to Fiscal Austerity. Comparative Political Studies 47(2): 143-170.

Kayser, Mark Andreas and Michael Peress (2016) The Buck Stops There? Benchmarking Elections in Open Economy. In Jack Vowles and Georgios Xezonalis (eds) Globalization and Domestic Politics: Parties, Elections, and Public Opinion. Oxford: Oxford University Press, 89-112.

Key, Valdimer O. (1966) The Responsible Electorate; Rationality in Presidential Voting, 19361960. Cambridge,: Belknap Press of Harvard University Press.

Kosmidis, Spyros (2018) International Constraints and Electoral Decisions: Does the Room to Maneuver Attenuate Economic Voting? American Journal of Political Science 62(3): 519534.

Laver, Michael and Kenneth Benoit (2015) The Basic Arithmetic of Legislative Decisions. American Journal of Political Science 59(2): 275-291.

Lewis-Beck, Michael S. and Costa M. Lobo (2017) The Economic Vote: Ordinary Vs Extraordinary Times. In Kai Arzheimer, Jocelyn Evans and Michael S. Lewis-Beck (eds) The Sage Handbook of Electoral Behaviour (Vol. 2). London: Sage, 606-629.

Lewis-Beck, Michael S. and Mary Stegmaier (2013) The Vp-Function Revisited: A Survey of the Literature on Vote and Popularity Functions after over 40 Years. Public Choice 157(3-4): 367-385.

Marsh, Michael and Slava Mikhaylov (2014) A Conservative Revolution: The Electoral Response to Economic Crisis in Ireland. Journal of Elections, Public Opinion and Parties 24(2): 160179.

Nannestad, Peter and Martin Paldam (1994) The Vp Function a Survey of the Literature on Vote and Popularity. Public Choice 79(3-4): 213-245.

Neumayer, Eric and Thomas Plümper (2017) Robustness Tests : Causal Inference with Observational Data. Cambridge, United Kingdom ; New York, NY, USA: University Printing House.

Pierson, Paul (ed.) (2001). The New Politics of the Welfare State. Oxford England ; New York: Oxford University Press. 
Powell, G. Bingham and Guy D. Whitten (1993) A Cross-National Analysis of Economic Voting:

Taking Account of the Political Context. American Journal of Political Science 37(2): 391414.

Raess, Damian and Jonas Pontusson (2015) The Politics of Fiscal Policy During Economic Downturns, 1981-2010. European Journal of Political Research 54(1): 1-22.

Rowe, Kelly T. (2015) Making Voice Count:Economic Voting and the Number of Parties. Party Politics 21(5): 803-812.

Ruiz-Rufino, RubÉN and Sonia Alonso (2017) Democracy without Choice: Citizens' Perceptions of Government Autonomy During the Eurozone Crisis. European Journal of Political Research 56(2): 320-345.

Salmon, Keith (2017) A Decade of Lost Growth: Economic Policy in Spain through the Great Recession. South European Society and Politics 22(2): 239-260.

Savage, Lee (2019) The Politics of Social Spending after the Great Recession: The Return of Partisan Policy Making. Governance 32(1): 123-141.

Schui, Florian (2014) Austerity : The Great Failure. New Haven: Yale University Press.

Silva, Carlos Nunes and Guy D. Whitten (2017) Clarity of Responsibility and Vote Choice. In Kai Arzheimer, Jocelyn Evans and Michael S. Lewis-Beck (eds) The Sage Handbook of Electoral Behaviour (Vol. 1). London: Sage, 584-605.

Stegmaier, Mary, Michael S. Lewis-Beck and Brandon Beomseob Park (2017) The Vp Function: A Review. In Kai Arzheimer, Jocelyn Evans and Michael S. Lewis-Beck (eds) The Sage Handbook of Electoral Behaviour (Vol. 2). London: Sage, 584-605.

Talving, Liisa (2017) The Electoral Consequences of Austerity: Economic Policy Voting in Europe in Times of Crisis. West European Politics 40(3): 560-583.

Weschle, Simon (2014) Two Types of Economic Voting: How Economic Conditions Jointly Affect Vote Choice and Turnout. Electoral Studies 34: 39-53.

\section{Author biography}

Marco Giuliani got is PhD in Political Science (1990) from the University of Florence (Italy), and now is full professor at the University of Milano where he teaches Comparative politics. His main research topics are the comparative analysis of the performance of democracies, electoral behavior, and EU politics and policy-making.

Table 1. Economic and austerity vote before and after the crisis

\begin{tabular}{lcccc}
\hline & \multicolumn{2}{c}{ Before the crisis } & \multicolumn{2}{c}{ During the crisis } \\
& $(1)$ & $(2000-2007)$ & $(3)$ & $(4)$ \\
\hline \multirow{3}{*}{ Lagged vote } & $0.55^{* * *}$ & $0.64^{* * *}$ & $0.78^{* * *}$ & $0.78^{* * *}$ \\
& $(0.12)$ & $(0.13)$ & $(0.09)$ & $(0.09)$ \\
Unemployment & $-1.14^{* * *}$ & $-0.82^{* *}$ & $-0.61^{* * *}$ & $-0.49^{* *}$ \\
& $(0.32)$ & $(0.37)$ & $(0.21)$ & $(0.22)$ \\
Growth & 0.78 & 0.79 & $0.87^{* *}$ & $0.85^{* *}$ \\
& $(0.49)$ & $(0.50)$ & $(0.41)$ & $(0.40)$
\end{tabular}




\begin{tabular}{lcccc} 
Austerity & & 0.52 & & $-1.28^{* *}$ \\
Coalition & & $(1.15)$ & & $(0.63)$ \\
& 4.82 & $5.73^{*}$ & 0.82 & 1.48 \\
Enep & $(2.97)$ & $(2.99)$ & $(2.76)$ & $(2.74)$ \\
& $-1.70^{* *}$ & $-1.45^{*}$ & $-1.30^{*}$ & $-1.29^{*}$ \\
Trend turnout & $(0.84)$ & $(0.88)$ & $(0.69)$ & $(0.68)$ \\
& $-0.26^{*}$ & -0.15 & $0.30^{*}$ & $0.28^{*}$ \\
Constant & $(0.15)$ & $(0.17)$ & $(0.17)$ & $(0.16)$ \\
& $26.19 * * *$ & $18.75^{* *}$ & $13.24^{* *}$ & $11.49^{* *}$ \\
& $(6.71)$ & $(7.79)$ & $(5.25)$ & $(5.25)$ \\
Observations & 79 & & & 80 \\
R-squared & 0.470 & 0.525 & 80 & 0.599 \\
Countries & 36 & 34 & 36 & 36 \\
\hline
\end{tabular}

Random effects; Standard errors in parentheses $* * * \mathrm{p}<0.01, * * \mathrm{p}<0.05, * \mathrm{p}<0.1$ 

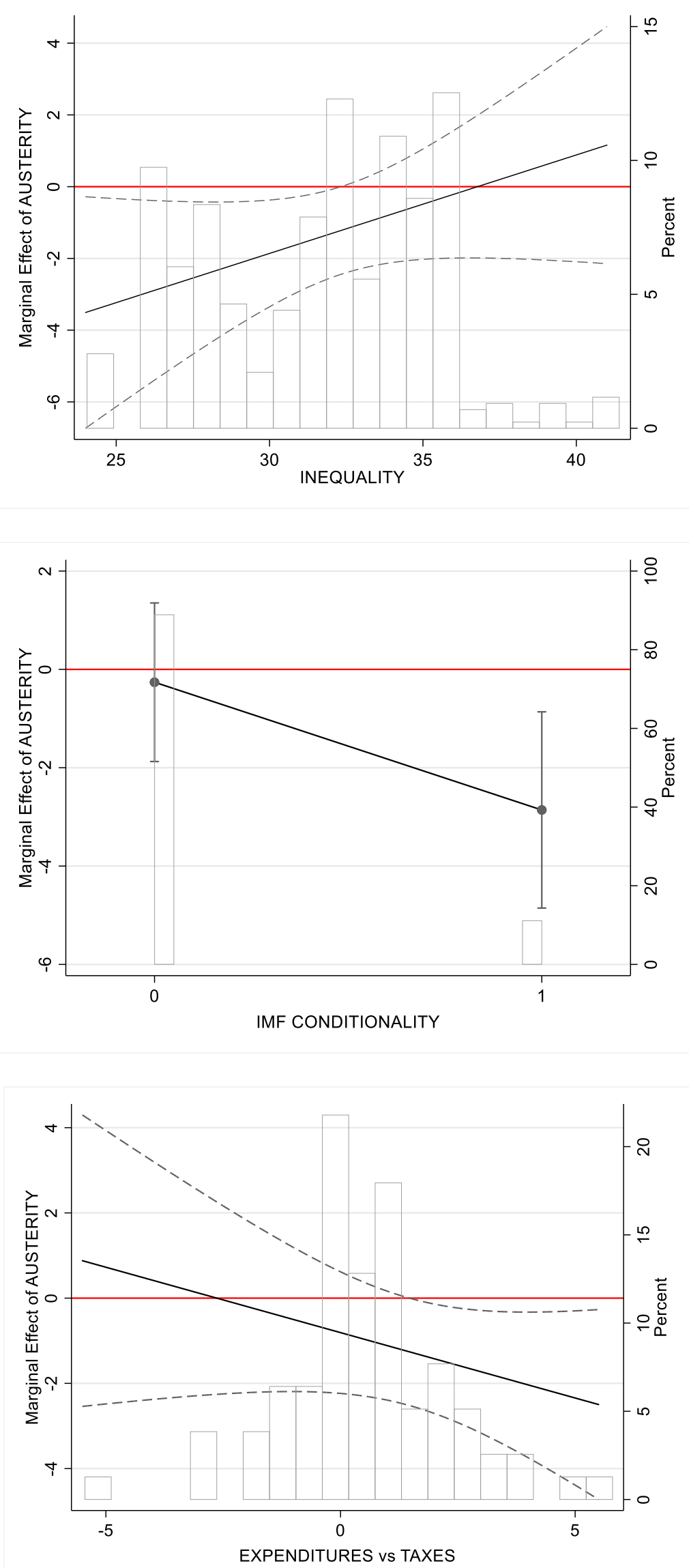

Figure 1 . Three conditional factors on the austerity vote 
Online Appendix to

\section{Economy or austerity. Drivers of retrospective voting before and during the Great Recession.}

\section{Contents}

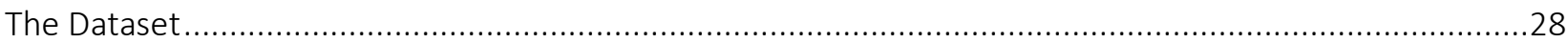

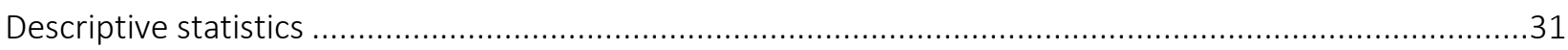

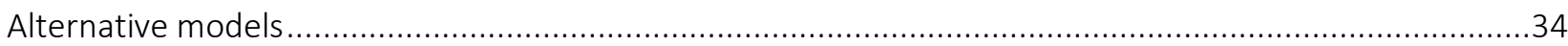

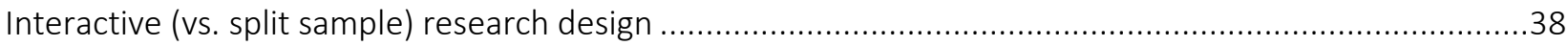

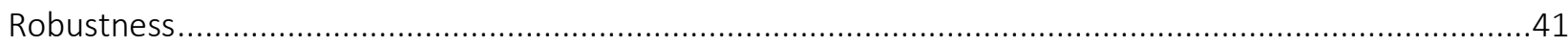

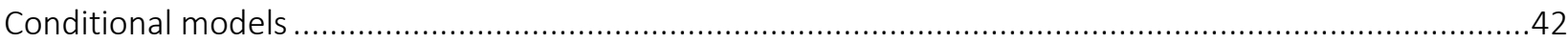

Tax-based vs Expenditure-based fiscal adjustment ..................................................................

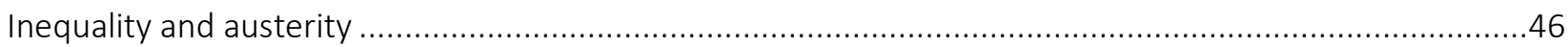

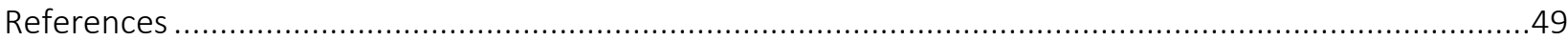




\section{The Dataset}

In what follows we present the codebook of the main variables included in the dataset, specifying the source of the information. For replication, the dataset is available on the author's personal webpage and uploaded in Harvard dataverse at https://doi.org/10.7910/DVN/RNXBS6

Table A.1 Codebook main variables in the dataset

\begin{tabular}{|c|c|c|}
\hline Variable & Description & Source \\
\hline $\begin{array}{l}\text { votesgov and } \\
\text { lagvotesgov }\end{array}$ & $\begin{array}{l}\text { Aggregated pct votes of incumbent parties } \\
\text { in an election and in the previous election }\end{array}$ & Parlgov, Wikipedia \\
\hline deltaturnout & $\begin{array}{l}\text { Trend in turnout: Change in turnout against } \\
\text { the previous election }\end{array}$ & Parlgov, Wikipedia \\
\hline enep & Effective number of electoral parties & Parlgov, Wikipedia \\
\hline coalition & Dummy variable for coalition & Parlgov, Wikipedia \\
\hline crisis & Dummy variable for the period 2008-2015 & \\
\hline wunemployment & $\begin{array}{l}\text { Weighted unemployment rate in the } 4 \\
\text { trimesters before the elections. } \\
\text { Unemployment rate computed as quarterly } \\
\text { weighted average of the annual } \\
\text { unemployment rates in the years before the } \\
\text { election. E.g. if an election took place in May } \\
2010 \text { (i.e. in the second quarter of } 2010 \text { ) we } \\
\text { produced a weighted index composed by } 1 / 4\end{array}$ & $\begin{array}{l}\text { IMF - Fiscal Monitor } \\
\text { October } 2018 \\
\text { The prefix "w" in } \\
\text { each variable reflects } \\
\text { a similar weighted } \\
\text { average, }\end{array}$ \\
\hline
\end{tabular}




\begin{tabular}{|c|c|c|}
\hline & $\begin{array}{l}\text { of the annual } 2010 \text { rate and by } 3 / 4 \text { of the } \\
\text { annual } 2009 \text { rate }\end{array}$ & \\
\hline wgrowth & $\begin{array}{l}\text { Weighted growth computed as quarterly } \\
\text { weighted average of the annual growth } \\
\text { levels in the years before the election, as in } \\
\text { wunemployment }\end{array}$ & $\begin{array}{l}\text { IMF - Fiscal Monitor } \\
\text { October } 2018\end{array}$ \\
\hline $\begin{array}{l}\text { wdeltaadjprimarybalanc } \\
\text { e }\end{array}$ & $\begin{array}{l}\text { Austerity index. Change in the weighted } \\
\text { cyclically adjusted primary balance (the } \\
\text { weight is computed as in the previous } \\
\text { economic variables) }\end{array}$ & $\begin{array}{l}\text { IMF - Fiscal Monitor } \\
\text { October } 2018\end{array}$ \\
\hline wdeltaexpenditures & $\begin{array}{l}\text { Change in the expenditures as percentage of } \\
\text { the GDP }\end{array}$ & $\begin{array}{l}\text { IMF - Fiscal Monitor } \\
\text { October } 2018\end{array}$ \\
\hline wdeltarevenues & $\begin{array}{l}\text { Change in the revenues as percentage of the } \\
\text { GDP }\end{array}$ & $\begin{array}{l}\text { IMF - Fiscal Monitor } \\
\text { October } 2018\end{array}$ \\
\hline imf & Dummy variable for IMF conditionality & $\begin{array}{l}\text { IMF } \\
\text { https://www.imf.org } \\
\text { lexternal/np/pdr/mo } \\
\text { na/index.aspx }\end{array}$ \\
\hline taxbase & $\begin{array}{l}\text { Index for expenditure- vs tax-based } \\
\text { austerity. (wdeltarevenues - } \\
\text { wdeltaexpenditures) }\end{array}$ & $\begin{array}{l}\text { IMF - Fiscal Monitor } \\
\text { October } 2018\end{array}$ \\
\hline
\end{tabular}




\begin{tabular}{|l|l|l|}
\hline wgini & $\begin{array}{l}\text { Gini index (weighted according to the timing } \\
\text { of the election) used for the multiple } \\
\text { imputation }\end{array}$ & World bank \\
\hline wginiadjusted & $\begin{array}{l}\text { Adjusted Gini index (then weighted } \\
\text { according the timing of the election), filling } \\
\text { in between missing values with the average } \\
\text { (only for the online appendix) }\end{array}$ & World bank \\
\hline
\end{tabular}


Table A.2 The average state of the economy (unemployment, growth, primary balance and debt)

\begin{tabular}{|c|c|c|c|c|c|c|c|c|}
\hline & \multicolumn{4}{|c|}{$2000-2007$} & \multicolumn{4}{|c|}{ 2008-2015 } \\
\hline & Unemp & Growth & $\begin{array}{l}\text { Primary } \\
\text { balance }\end{array}$ & $\begin{array}{l}\text { Gross } \\
\text { debt }\end{array}$ & Unemp & Growth & $\begin{array}{l}\text { Primary } \\
\text { balance }\end{array}$ & $\begin{array}{c}\text { Gross } \\
\text { debt }\end{array}$ \\
\hline Australia & 5.6 & 3.4 & 1.3 & 13.4 & 5.4 & 2.6 & -2.9 & 25.5 \\
\hline Austria & 4.8 & 2.4 & 0.3 & 66.1 & 5.1 & 0.6 & -0.6 & 80.4 \\
\hline Belgium & 7.7 & 2.3 & 4.2 & 98.9 & 7.9 & 0.8 & -0.3 & 102.2 \\
\hline Canada & 7.0 & 2.9 & 2.8 & 74.8 & 7.3 & 1.6 & -1.3 & 82.0 \\
\hline Croatia & 18.7 & 4.5 & -2.7 & 37.6 & 17.1 & -1.0 & -2.7 & 66.8 \\
\hline Cyprus & 4.3 & 4.1 & 0.0 & 59.8 & 10.2 & -0.6 & -0.6 & 76.8 \\
\hline Czech Republic & 7.6 & 4.6 & -3.4 & 25.7 & 6.3 & 1.1 & -1.8 & 38.8 \\
\hline Denmark & 4.6 & 1.9 & 4.0 & 42.1 & 6.5 & 0.3 & -0.7 & 41.9 \\
\hline Estonia & 9.7 & 8.0 & 1.3 & 4.9 & 10.0 & 0.1 & -0.6 & 8.1 \\
\hline Finland & 8.7 & 3.5 & 4.0 & 40.1 & 8.1 & -0.6 & -1.6 & 50.5 \\
\hline France & 8.6 & 2.1 & -0.1 & 63.0 & 9.5 & 0.6 & -2.6 & 87.4 \\
\hline Germany & 9.3 & 1.7 & 0.2 & 62.6 & 6.0 & 1.0 & 0.9 & 75.0 \\
\hline Greece & 10.1 & 4.1 & -1.1 & 104.4 & 18.9 & -3.7 & -3.0 & 157.4 \\
\hline Hungary & 6.5 & 3.8 & -2.6 & 58.4 & 9.5 & 0.6 & 0.4 & 77.3 \\
\hline Iceland & 2.7 & 5.1 & 2.3 & 33.8 & 5.7 & 0.7 & -2.7 & 80.2 \\
\hline Ireland & 4.7 & 5.8 & 2.5 & 29.0 & 12.6 & 3.9 & -8.2 & 90.2 \\
\hline Israel & 11.6 & 3.9 & 1.6 & 84.9 & 7.1 & 3.5 & -0.2 & 69.0 \\
\hline Italy & 8.1 & 1.5 & 1.8 & 102.1 & 9.8 & -1.0 & 1.0 & 120.3 \\
\hline Japan & 4.7 & 1.5 & -5.1 & 163.1 & 4.3 & 0.4 & -6.6 & 217.9 \\
\hline Korea & 3.7 & 5.4 & 2.8 & 22.6 & 3.4 & 3.1 & 0.3 & 33.3 \\
\hline Latvia & 10.9 & 8.5 & -0.6 & 11.8 & 13.6 & -0.5 & -1.6 & 34.0 \\
\hline Lithuania & 11.1 & 7.6 & -1.0 & 19.8 & 12.2 & 1.0 & -2.9 & 34.8 \\
\hline Luxembourg & 3.3 & 4.6 & 1.4 & 7.1 & 6.1 & 1.7 & 0.4 & 19.9 \\
\hline Malta & 7.5 & 1.9 & -1.0 & 67.0 & 6.7 & 3.8 & 0.4 & 65.8 \\
\hline Netherlands & 4.5 & 2.3 & 1.3 & 47.4 & 5.7 & 0.5 & -1.8 & 61.6 \\
\hline New Zealand & 4.6 & 3.7 & 4.9 & 23.4 & 5.6 & 2.0 & -1.2 & 30.8 \\
\hline Norway & 3.8 & 2.5 & 11.2 & 39.7 & 3.6 & 1.0 & 9.3 & 35.3 \\
\hline Poland & 16.7 & 4.0 & -1.4 & 43.1 & 8.9 & 3.2 & -2.3 & 51.7 \\
\hline Portugal & 6.1 & 1.5 & -2.1 & 60.7 & 12.3 & -0.6 & -3.1 & 109.0 \\
\hline Slovakia & 16.8 & 5.7 & -3.1 & 39.8 & 12.9 & 2.2 & -3.0 & 45.3 \\
\hline Slovenia & 6.2 & 4.3 & 0.2 & 26.8 & 7.9 & -0.2 & -3.6 & 53.5 \\
\hline Spain & 10.5 & 3.8 & 2.3 & 46.6 & 21.0 & -0.4 & -5.8 & 75.3 \\
\hline Sweden & 6.6 & 3.3 & 2.5 & 47.2 & 7.8 & 1.4 & -0.1 & 40.2 \\
\hline Switzerland & 2.9 & 2.5 & 0.6 & 54.2 & 3.1 & 1.4 & 0.9 & 43.5 \\
\hline United Kingdom & 5.2 & 2.8 & -0.4 & 37.8 & 7.1 & 0.9 & -4.9 & 76.7 \\
\hline United States & 5.0 & 2.7 & -1.2 & 61.2 & 7.6 & 1.4 & -5.6 & 96.7 \\
\hline
\end{tabular}


The data reported in Table A.2 illustrate the state of the economy in the two periods considered by our analysis. They represent the average of the whole series of annual economic indices downloaded from the IMF Fiscal monitor.

The summary statistics reported in Table A.3 refer instead to the values estimated in the year (i.e. four trimesters) before the election, following the conventional measure described in the article and in Table A.1 (i.e. weighting the annual values according to the trimester of the election). They confirm the high variability in all the variables used both across and within each of the two periods.

Regarding the political variables, the Great Recession evidenced a clear average increase in the cost of governing (i.e. decrease in the change of votes for incumbent parties) yet without any significant change in the range of this variable. We observed the same cross-period variability also regarding the trend in turnout, though in a slightly more fragmented context (a 10\% increase in the effective number of parties).

Table A.3 Descriptive statistics of the main variables in the two periods, estimated in the year before the election

\section{Before (2000-2007)}

During (2008-2015)

Variable Mean Std. Dev. Min / Max Mean Std. Dev. Min / Max

\begin{tabular}{lcccccc}
\hline Trend votes (pct) & -3.49 & 9.85 & $-45.5 / 13.4$ & -7.83 & 10.25 & $-48.1 / 13.1$ \\
Unemployment & 7.25 & 3.67 & $2.8 / 19.2$ & 8.60 & 4.86 & $3.0 / 26.5$ \\
Trend & -0.26 & 0.94 & $-4.1 / 2.6$ & 0.23 & 1.29 & $-2.2 / 5.5$ \\
unemployment & & & & & & \\
Growth & 3.47 & 2.28 & $-0.2 / 11.6$ & 0.98 & 2.53 & $-8.65 / 5.1$ \\
Primary balance & 0.62 & 3.36 & $-6.8 / 12.4$ & -2.10 & 4.88 & $-29.7 / 11.8$ \\
& & & & & &
\end{tabular}




\begin{tabular}{lcccccc}
\hline Gross Debt & 54.58 & 33.81 & $4.4 / 174.2$ & 69.26 & 44.69 & $6.6 / 235.2$ \\
Austerity & -0.35 & 1.04 & $-3.3 / 2.0$ & 0.02 & 1.59 & $-6.4 / 5.0$ \\
Trend turnout & -0.95 & 6.54 & $-18.2 / 19.1$ & -0.92 & 5.88 & $-20.4 / 19.7$ \\
Enep & 4.55 & 1.66 & $2.0 / 9.9$ & 4.99 & 1.84 & $2.0 / 11.0$ \\
Inequality & 31.61 & 4.07 & $24.8 / 41.7$ & 32.20 & 4.30 & $24.1 / 41.8$ \\
& & & & & &
\end{tabular}

Note: Data refer to cases included in the complete model of Table 1

In regard to the economic variables, although some swift recovery from the crisis moderated the comparison between the two periods, the Great Recession produced an overall deterioration of the economic environment in the whole 7-year period, i.e. also some years after its onset. Compared to the pre-crisis period there was higher $(+1.4 \%)$ and increasing unemployment $(+0.5 \%)$, widespread stagnation (almost $-2.5 \%$ in growth), negative primary balance $(-2.7 \%)$ and increasing debt $(+14.7 \%)$. Countries reacted differently to this global context, and though there was an average increase in restrictive policies (i.e. greater austerity), there was also an increase in their diversity. Usually, the political cycle suggests moderation in election years, and this is reflected in the difference between our summary statistics and the high variability in austerity policies shown in Figure A.1 for both periods.

More in detail, there were contractionary policies - i.e. a positive change in the cyclically adjusted primary balance against the previous year - even before 2018, and expansionary ones even after the onset of the crisis. The scatterplot of figure A.1 illustrate the cross-country and cross-time variation in this austerity measure. 


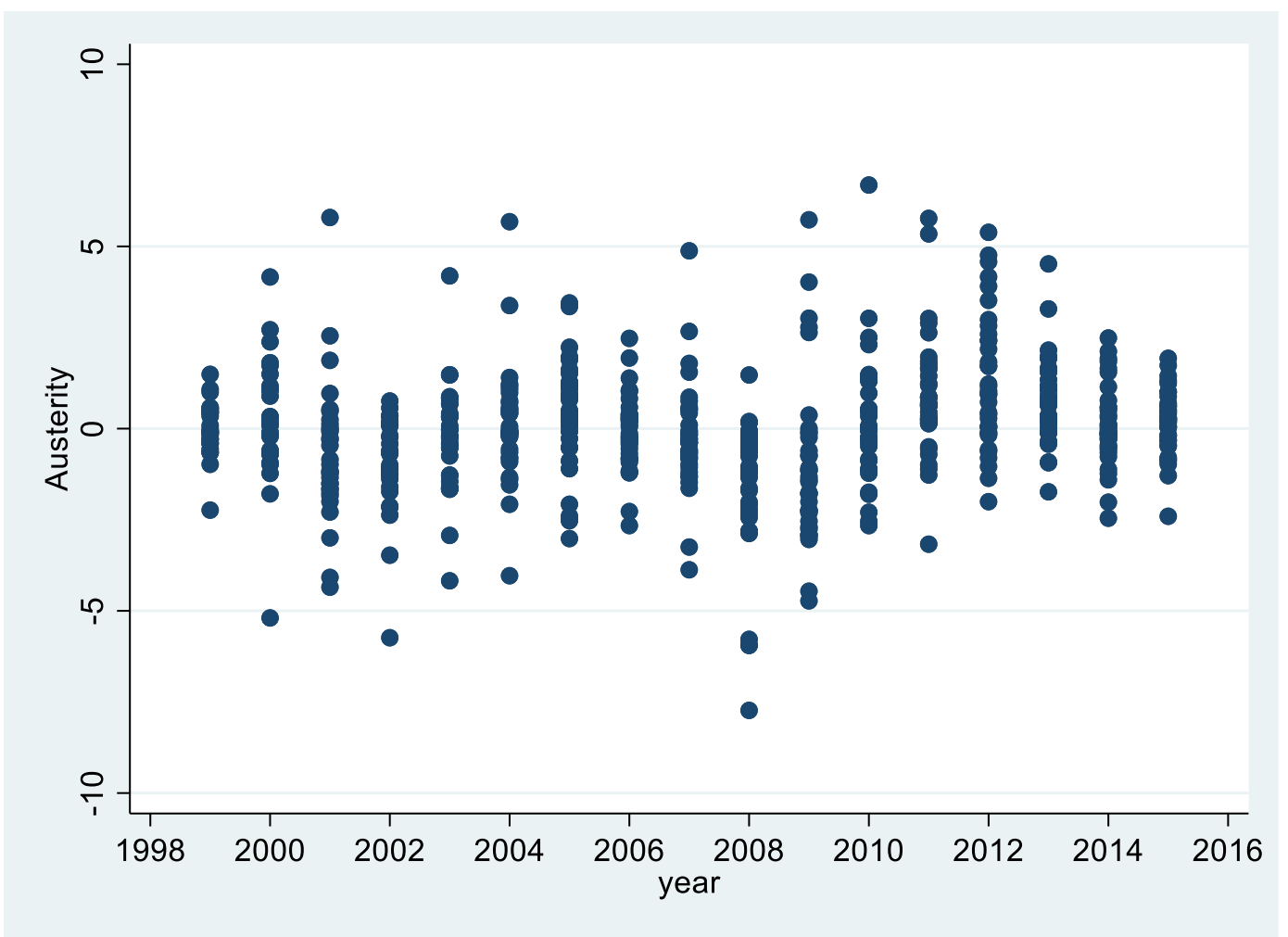

Fig. A1 Austerity measure (change in adjusted primary balance)

\section{Alternative models}

An alternative to our Random Effects (RE) panel regression would have been using Fixed Effects (FE), as standard way to cope with unobserved heterogeneity. We here explain why, in our specific circumstances and for our research design, this wouldn't have been a sound choice, report the alternative results of the baseline complete models of Table 1 using FE (instead of our strategy with lagged dependent variable and RE), and the results of the corresponding Hausman tests. 
Table A.4 reports the coefficient for these alternative models.

Table A.4 The alternative specification with Fixed effects

(1)

$(2)$

\begin{tabular}{lcc}
\hline & & \\
Unemployment & $-1.65^{*}$ & -0.67 \\
& $(0.90)$ & $(0.48)$ \\
Growth & 0.87 & 0.95 \\
& $(0.78)$ & $(0.64)$ \\
Austerity & 0.89 & -1.16 \\
& $(1.46)$ & $(0.82)$ \\
Coalition & 7.82 & 5.66 \\
& $(5.47)$ & $(5.99)$ \\
Enep & $-3.66^{* *}$ & 0.87 \\
& $(1.77)$ & $(1.70)$ \\
Trend turnout & -0.19 & 0.09 \\
& $(0.19)$ & $(0.20)$ \\
Constant & $61.86^{* * *}$ & $35.62 * * *$ \\
& $(11.22)$ & $(8.86)$ \\
Observations & & 80 \\
Countries & 70 & 36 \\
rho & 34 & 0.59 \\
\hline
\end{tabular}

Fixed effects; Standard errors in parentheses $* * * p<0.01,{ }^{* *} p<0.05, * p<0.1$

As it can be seen, the signs of the covariates of interests are correct (or in line with the RE models),

but almost never significant, especially during the crisis period.

Firstly, from a statistical perspective, there is not enough statistical power in the sample to use FE:

- most of the variance in the support for incumbents is cross-country, and not longitudinal: running standard FE highlights that between $60 \%$ and $70 \%$ of the variance is cross-panel (this quantity even reaches $80 \%$ of the overall variance in case of some conditional models in the second part of the article).

- FE work better with longer time series, but only one country out of four had more than two elections before or during the crisis: i.e. since "FE models can say (...) only about deviations from the mean over time" (Bell, Fairbrother and Jones, 2018: 1058), it is not surprising that they did not fit well in our analysis. As an indirect proof of this argument, also the standard variables of the economic vote in Table A.4 - unemployment and growth - turned out to be mostly not significant using that approach. 
- the option of extending the sample to increase the statistical power was unavailable, since the sample actually covered the universe of economically advanced and consolidated democracies. By enlarging the sample in a cross-country direction, we would have included either non-democratic countries or non-advanced economies, which would have resulted in confounding the actual meaning of the indices (punishing incumbents in non-democratic settings, or levels of unemployment in non-developed economies have different meanings). Extending the temporal horizon would have been impossible: we chose 2015 as final date because in that year, the labour market of most of the countries included in the sample had returned to pre-crisis levels.

Secondly, methodologically speaking, and as argued by Bell and Jones (2014: 134), "FE models effectively cut out much of what is going on - goings-on that are usually of interest to the researcher, the reader and the policy maker". As clarified in the previous paragraph, most of those "goings-on", the between-countries variation, would have been cancelled by the use of FE. In these situations, as Neumayer and Plümper (2017: 134-135) explain “Between-variation is information. Differencing and fixed-effects estimation eliminate valuable information. In fact, both techniques eliminate more information - all the between-variation - than they would do in an optimal world, in which they would merely eliminate the variance of the regressors correlated with the omitted time-invariant variables. This leads to a loss of efficiency, which can be substantial if the within-variation is low and the between variation is high" (which is our case). Furthermore, FE also "implicitly change the hypotheses tested in subtle ways" (Neumayer and Plümper, 2017: 135): from 'the more austerity, the more electoral punishment' to 'the larger the increase in austerity (within the same unit), the more electoral punishment'. Incidentally, adopting OLS with robust or country-clustered standard errors returns substantially similar results for the crisis period.

Thirdly, although it is a standard econometric practice to use FE to cope with unobserved heterogeneity, it very much depends on the quality of that heterogeneity, which is only presumed to be time-invariant. "For many causal questions, the notion that the most important omitted variables are time invariant doesn't seem plausible"(Angrist and Pischke, 2009: 243). Otherwise, the solution could be worse than the problem. An alternative option is to use a lagged dependent variable in the 
right-hand side of the equation (as we did). Also this solution has its own limits, as pointed out by Achen (2001), but it is not without some merits (Beck and Katz, 2011; Keele and Kelly, 2017).

Whereas scholars should ideally aim at robust results indifferent to the model specifications, thus trying both FE and LDV models (Angrist and Pischke, 2009), this option does not always work. In that event, statistical tests could help in making the most appropriate choice. In our case, using the Hausman test to compare the first option against random effects models, always indicated adopting a RE specification. Before the Great Recession, contrasting FE and RE models, the test for the null hypothesis of non-systematic differences was greater than 0.22 , whereas during the crisis greater than 0.95 . 
In the analysis reported in this article, we preferred to adopt a split-sample research design because of its immediate appeal and intuitive interpretation. Yet our findings were confirmed even when interacting our covariates with a dummy variable representing the crisis period.

In figure A.2 below we plot the marginal effect of our covariates, bearing in mind that "the analyst is not directly interested in the significance or insignificance of the model parameters per se" (Brambor, Clark and Golder, 2006: 70), but should rather "plot $\mathrm{q}^{\wedge} \mathrm{y}=\mathrm{qx}$ over an appropriate range of $\mathrm{z}$ along with confidence intervals" (Kam and Franzese, 2007: 46) and superimpose the "frequency distribution for the variable on the horizontal axis" (Berry, Golder and Milton, 2012: 16).

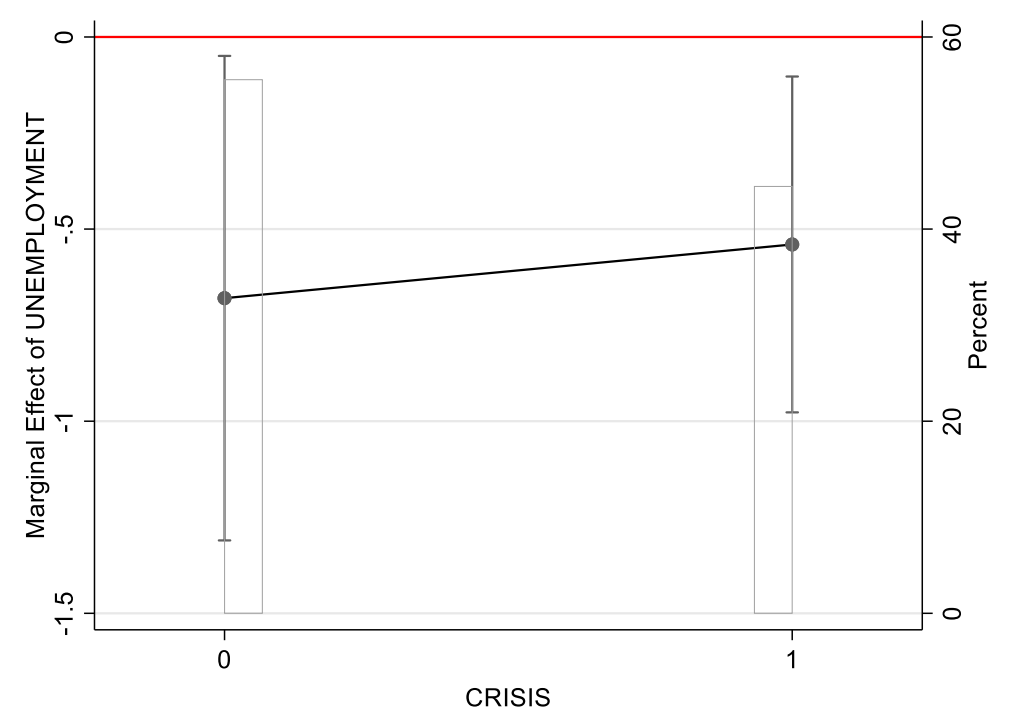



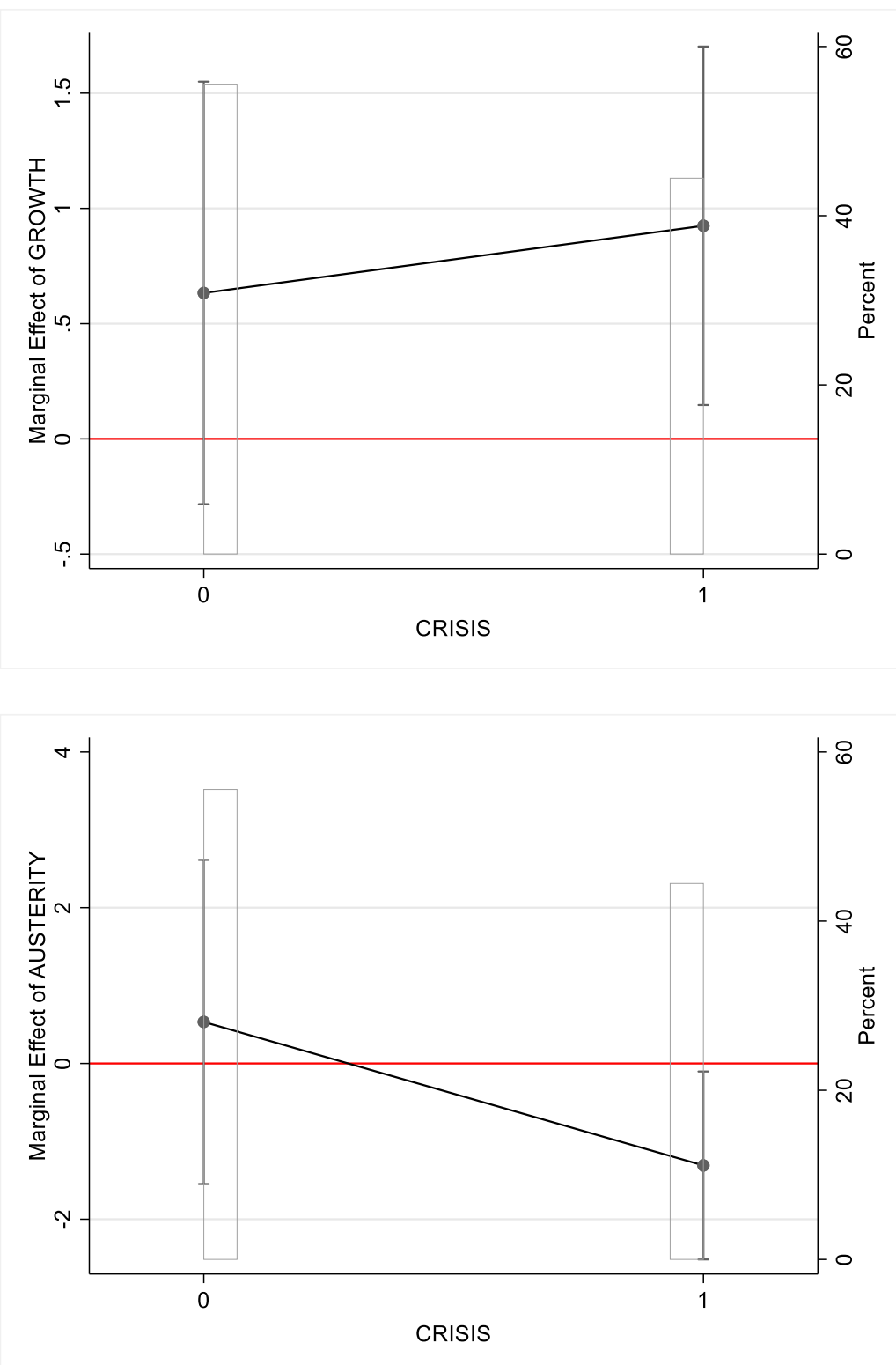

Fig. A.2 Marginal effects (with 95\% confidence intervals) of economic and policy variables (separated) on the percentage of votes gained by incumbent parties before and during the crisis

Figure A.2 reproduces the marginal effects of economic and policy variables before and during the crisis, thus replicating with a different strategy the full models ( 2 and 4 ) of table 1 in the text. In both cases, we observe:

a) The enduring significance of the levels of unemployment before and during the crisis, confirming the economic voting theory in ordinary and exceptional periods; furthermore, the effect of this variable is clearer in tough times, as testified by the smaller confidence intervals. 
b) The increasing importance of the economy in the extraordinary period of the Great Recession, in which also growth (on top of unemployment) impacts on the electoral fate of incumbents.

c) The diverse impact of austerity measures in the two periods, with insignificant marginal effects before the Great Recession and negative ones after the onset of the crisis (even if controlled by unemployment and growth). In the text we have demonstrated how these average effects should be further split depending on several conditional factors, improving/moderating the substantial effect of austerity in the crisis period.

Thus, all these interacting models confirm the same results obtained in the text by adopting a splitsample research design. 


\section{Robustness}

For robustness, we included a series of alternative model specifications in regard to the economic variables used.

Firstly, we replicated the full models replacing the level of unemployment with its trend variable, and then adding the latter to the original model (Table A.5).

The results presented in the text are confirmed. Austerity behaves exactly as before (and as expected), with a coefficient which is not statistically significant before the crisis and that turns negative and highly significant during the Great Recession. Amongst the economic variables, the level of unemployment is the one that mostly triggers the economic vote, with growth being only sometimes weakly significant, and the trend in unemployment having the correct negative sign but never reaching a sufficient level of statistical significance.

Table A.5 Complete models with austerity, separating level and trend in unemployment

\begin{tabular}{|c|c|c|c|c|}
\hline & \multicolumn{2}{|c|}{$\begin{array}{c}\text { Before the crisis } \\
(2000-2007)\end{array}$} & \multicolumn{2}{|c|}{$\begin{array}{c}\text { During the crisis } \\
(2008-2015)\end{array}$} \\
\hline & $(1)$ & $(2)$ & $(3)$ & $(4)$ \\
\hline Lagged vote & $\begin{array}{c}0.71 * * * \\
(0.13)\end{array}$ & $\begin{array}{c}0.67 * * * \\
(0.13)\end{array}$ & $\begin{array}{c}0.80 * * * \\
(0.09)\end{array}$ & $\begin{array}{c}0.78 * * * \\
(0.09)\end{array}$ \\
\hline Unemployment & & $\begin{array}{c}-0.81^{* *} \\
(0.37)\end{array}$ & & $\begin{array}{c}-0.49 * * \\
(0.22)\end{array}$ \\
\hline Trend unemployment & $\begin{array}{l}-1.53 \\
(1.48)\end{array}$ & $\begin{array}{l}-1.47 \\
(1.46)\end{array}$ & $\begin{array}{l}-0.06 \\
(1.07)\end{array}$ & $\begin{array}{l}-0.06 \\
(1.04)\end{array}$ \\
\hline Growth & $\begin{array}{c}0.38 \\
(0.65)\end{array}$ & $\begin{array}{c}0.38 \\
(0.63)\end{array}$ & $\begin{array}{l}1.01^{*} \\
(0.56)\end{array}$ & $\begin{array}{c}0.83 \\
(0.55)\end{array}$ \\
\hline Austerity & $\begin{array}{c}0.02 \\
(1.20)\end{array}$ & $\begin{array}{c}0.29 \\
(1.18)\end{array}$ & $\begin{array}{c}-1.65^{* * *} \\
(0.62)\end{array}$ & $\begin{array}{c}-1.27^{* *} \\
(0.63)\end{array}$ \\
\hline Coalition & $\begin{array}{l}5.76^{*} \\
(3.11)\end{array}$ & $\begin{array}{l}5.21^{*} \\
(2.99)\end{array}$ & $\begin{array}{c}1.66 \\
(2.87)\end{array}$ & $\begin{array}{c}1.46 \\
(2.78)\end{array}$ \\
\hline Enep & $\begin{array}{c}-1.89 * * \\
(0.88)\end{array}$ & $\begin{array}{l}-1.42 \\
(0.87)\end{array}$ & $\begin{array}{c}-1.40 * * \\
(0.71)\end{array}$ & $\begin{array}{l}-1.29 * \\
(0.68)\end{array}$ \\
\hline Trend turnout & $\begin{array}{c}-0.11 \\
(0.18)\end{array}$ & $\begin{array}{l}-0.17 \\
(0.18)\end{array}$ & $\begin{array}{c}0.27 \\
(0.17)\end{array}$ & $\begin{array}{l}0.28^{*} \\
(0.16)\end{array}$ \\
\hline
\end{tabular}




\begin{tabular}{lcccc} 
Constant & $12.33^{*}$ & $18.43^{* *}$ & 6.55 & $11.57^{* *}$ \\
& $(7.39)$ & $(7.70)$ & $(4.93)$ & $(5.34)$ \\
Observations & & & & \\
R-squared & 70 & 70 & 80 & 80 \\
Countries & 0.483 & 0.535 & 0.571 & 0.599 \\
\hline
\end{tabular}

Random effects; Standard errors in parentheses *** $p<0.01, * * p<0.05, * p<0.1$

\section{Conditional models}

We report below the full models of the conditional models presented in the article. The low statistical significance of the interaction terms does not in any respect affect the substance of the finding. As Brambor, Clark and Golder (2006) have made clear, we should not be interested in the significance of those coefficients, but directly in the marginal effects of our covariate at different intensities of the interacting term (Berry, Golder and Milton, 2012; Kam and Franzese, 2007).

Table A.6 The conditional models of Figure 1 in the article
(1)
(2)
(3)

\begin{tabular}{lccc}
\hline & & & \\
Lagged vote & $0.72^{* * *}$ & $0.83^{* * *}$ & $0.84^{* * *}$ \\
Unemployment & $(0.09)$ & $(0.09)$ & $(0.09)$ \\
& $-0.64^{* *}$ & $-0.39 *$ & $-0.46^{* *}$ \\
Growth & $(0.24)$ & $(0.23)$ & $(0.21)$ \\
& $0.90^{* *}$ & 0.57 & 0.59 \\
Austerity & $(0.41)$ & $(0.41)$ & $(0.42)$ \\
& $-10.10^{*}$ & -0.26 & -0.76 \\
Inequality & $(5.92)$ & $(0.82)$ & $(0.72)$ \\
IMF & 0.50 & & \\
Expenditures vs Taxes & $(0.34)$ & & \\
Austerity*Inequality & & -3.27 & -0.46 \\
Austerity*IMF & & $(3.27)$ & $(0.41)$ \\
Austerity*Exp vs Tax & & & \\
& 0.27 & & \\
& $(0.18)$ & & $(0.21)$
\end{tabular}




\begin{tabular}{lccc} 
Coalition & 4.19 & 0.19 & 1.11 \\
& $(3.16)$ & $(2.84)$ & $(2.59)$ \\
Enep & $-1.53^{* *}$ & $-1.17^{*}$ & $-1.36^{* *}$ \\
& $(0.70)$ & $(0.68)$ & $(0.64)$ \\
Trend turnout & $0.28^{*}$ & $0.27^{*}$ & $0.29^{*}$ \\
& $(0.16)$ & $(0.16)$ & $(0.16)$ \\
Constant & -0.83 & $9.56^{*}$ & $9.62^{*}$ \\
& $(10.86)$ & $(5.21)$ & $(5.20)$ \\
Observations & & & \\
R-squared & 75 & 80 & 80 \\
Countries & -- & 0.624 & 0.643 \\
\hline
\end{tabular}

Note: R-squared is not computed for multiple imputations. 


\section{Tax-based vs Expenditure-based fiscal adjustment}

In the text we have interacted austerity with an index measuring the internal balance between service cuts and tax increases, using the IMF Fiscal Monitor data for expenditures and revenues.

An alternative way to test potentially different effects of the two major components of fiscal readjustments is to include them directly in a regression model as in Table A.6. The first model includes only the trend in expenditures, model 2 only the trend in taxation, and the full model 3 both of them.

The results are coherent with the conditional model proposed in the article, with, besides the wellknown role of unemployment, only the increase in taxation levels triggering the punishment of incumbents.

Table A.7 Tax-based and Expenditure based adjustment and incumbents' performance during the crisis

(1)

\begin{tabular}{lccc}
\hline & & & \\
Lagged vote & $0.78^{* * *}$ & $0.77^{* * *}$ & $0.79 * *$ \\
Unemployment & $(0.09)$ & $(0.09)$ & $(0.09)$ \\
& $-0.64^{* * *}$ & $-0.62^{* * *}$ & $-0.65^{* * *}$ \\
Growth & $(0.21)$ & $(0.21)$ & $(0.21)$ \\
& 0.65 & $0.78^{*}$ & 0.53 \\
Trend expenditures & $(0.43)$ & $(0.41)$ & $(0.43)$ \\
& -0.54 & & -0.62 \\
Trend revenues & $(0.39)$ & & $(0.39)$ \\
& & $-1.67^{*}$ & $-1.73^{*}$ \\
Coalition & & $(0.97)$ & $(0.97)$ \\
& 0.77 & 0.92 & 0.80 \\
Enep & $(2.71)$ & $(2.77)$ & $(2.67)$ \\
& $-1.30^{*}$ & $-1.25^{*}$ & $-1.24 *$ \\
Trend turnout & $(0.67)$ & $(0.69)$ & $(0.66)$ \\
& $0.34^{* *}$ & 0.25 & $0.29^{*}$ \\
Constant & $(0.17)$ & $(0.17)$ & $(0.17)$ \\
& $13.84^{* * *}$ & $13.28^{* *}$ & $13.38^{* * *}$
\end{tabular}


Observations

80

80

80

R-squared

0.588

0.591

0.606

Countries

36

36

36

Random effects; Standard errors in parentheses $* * * p<0.01, * * p<0.05, * p<0.1$ 


\section{Inequality and austerity}

The problem in interacting inequality and austerity was once again the availability of data. We chose the Gini index as a measure of income inequality, and the best source of data for the country and period covered in the article is the World Bank dataset.

Unfortunately, even that source has some missing data. Because of the way in which we computed the weighted average for each of our variables, adjusting the index to the timing of the election, the problem of missing values was further magnified. We needed two consecutive annual data points to estimate our trimester adjusted measure.

Table A.8 Interacting austerity and inequality (two different imputation strategies)

\begin{tabular}{|c|c|c|}
\hline & $\begin{array}{c}\text { Multiple } \\
\text { imputation }\end{array}$ & $\begin{array}{c}\text { Average for } \\
\text { Missing values }\end{array}$ \\
\hline Lagged vote & $\begin{array}{c}0.72 * * * \\
(0.09)\end{array}$ & $\begin{array}{c}0.76^{* * *} \\
(0.09)\end{array}$ \\
\hline Unemployment weighted & $\begin{array}{c}-0.64 * * * \\
(0.24)\end{array}$ & $\begin{array}{c}-0.58 * * \\
(0.22)\end{array}$ \\
\hline Growth weighted & $\begin{array}{c}0.90 * * \\
(0.41)\end{array}$ & $\begin{array}{c}0.89 * * \\
(0.41)\end{array}$ \\
\hline Austerity & $\begin{array}{c}-10.10^{*} \\
(5.92)\end{array}$ & $\begin{array}{c}-10.73^{* *} \\
(4.98)\end{array}$ \\
\hline Inequality & $\begin{array}{c}0.50 \\
(0.34)\end{array}$ & $\begin{array}{c}0.37 \\
(0.27)\end{array}$ \\
\hline Austerity*Inequality & $\begin{array}{c}0.27 \\
(0.18)\end{array}$ & $\begin{array}{l}0.29 * \\
(0.15)\end{array}$ \\
\hline Coalition & $\begin{array}{c}4.19 \\
(3.16)\end{array}$ & $\begin{array}{c}4.02 \\
(3.05)\end{array}$ \\
\hline Enep & $\begin{array}{c}-1.53^{* *} \\
(0.70)\end{array}$ & $\begin{array}{c}-1.49 * * \\
(0.69)\end{array}$ \\
\hline Trend turnout & $\begin{array}{l}0.28^{*} \\
(0.16)\end{array}$ & $\begin{array}{l}0.28^{*} \\
(0.16)\end{array}$ \\
\hline Constant & $\begin{array}{c}-0.83 \\
(10.87)\end{array}$ & $\begin{array}{c}0.95 \\
(9.53)\end{array}$ \\
\hline Observations & 75 & 75 \\
\hline Number of id & 34 & 34 \\
\hline
\end{tabular}




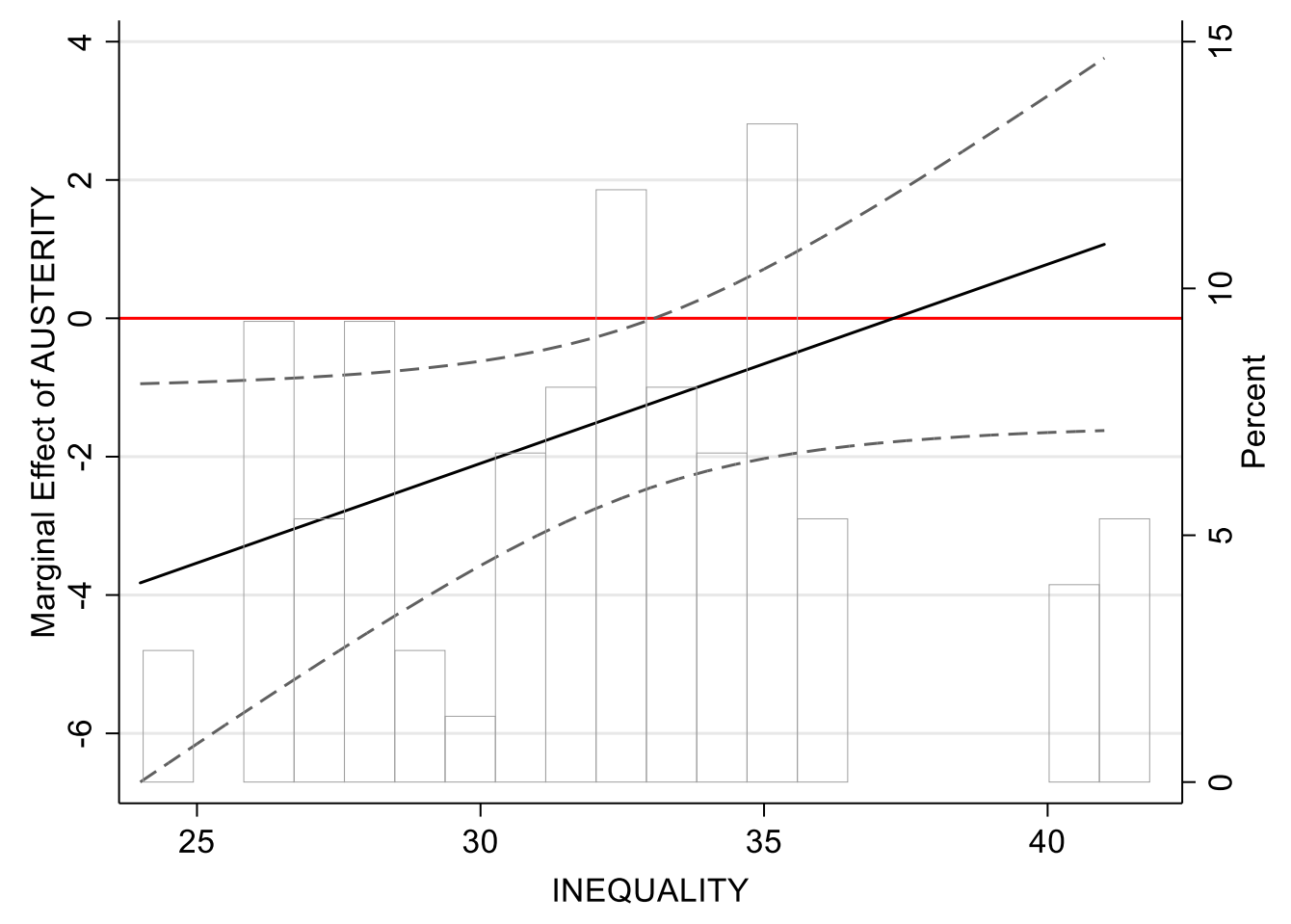

Figure A.3 The conditional role of inequality on austerity vote adopting our second imputation of missing values 


\section{References}

Achen, Christopher (2001) Why Lagged Dependent Variables Can Suppress Explanatory Power. Angrist, Joshua David and Jörn-Steffen Pischke (2009) Mostly Harmless Econometrics : An Empiricist's Companion. Princeton: Princeton University Press.

Beck, Nathaniel and Jonathan N. Katz (2011) Modeling Dynamics in Time-Series-Cross-Section Political Economy Data. Annual Review of Political Science 14(1): 331-352.

Bell, Andrew, Malcolm Fairbrother and Kelvyn Jones (2018) Fixed and Random Effects Models: Making an Informed Choice. Quality \& Quantity 53(2): 1051-1074.

Bell, Andrew and Kelvyn Jones (2014) Explaining Fixed Effects: Random Effects Modeling of TimeSeries Cross-Sectional and Panel Data. Political Science Research and Methods 3(1): 133153.

Berry, William D., Matt Golder and Daniel Milton (2012) Improving Tests of Theories Positing Interaction. The Journal of Politics 74(3): 653-671.

Brambor, Thomas, William Roberts Clark and Matt Golder (2006) Understanding Interaction Models: Improving Empirical Analyses. Political Analysis 14(1): 63-82.

Kam, Cindy D. and Robert J. Franzese (2007) Modeling and Interpreting Interactive Hypotheses in Regression Analysis. Ann Arbor: University of Michigan Press.

Keele, Luke and Nathan J. Kelly (2017) Dynamic Models for Dynamic Theories: The Ins and Outs of Lagged Dependent Variables. Political Analysis 14(2): 186-205.

Neumayer, Eric and Thomas Plümper (2017) Robustness Tests : Causal Inference with Observational Data. Cambridge, United Kingdom; New York, NY, USA: University Printing House.

i. Hübscher and Sattler (2017) demonstrate that these results tend to underestimate the electoral risks connected with fiscal adjustments because they fail to consider the strategic choices of governments that concentrate the necessary consolidation in the honeymoon period after the election hoping to have the time to dilute the electoral consequences before the end of their mandate.

ii. To our knowledge, rising inequality per se has only rarely been considered an issue triggering electoral punishment (Dassonneville and Lewis-Beck, 2019b), and it has never been taken into account as a factor conditioning that behavior.

iii. The complete list is the following: Australia, Austria, Belgium, Canada, Croatia, Cyprus, Czech Republic, Denmark, Estonia, Finland, France, Germany, Greece, Hungary, Iceland, Ireland, Israel, Italy, Japan, Korea, Latvia, Lithuania, Luxembourg, Malta, Netherlands, New Zealand, Norway, Poland, Portugal, Slovakia, Slovenia, Spain, Sweden, Switzerland, United Kingdom, 
United States. Other OECD countries, like Mexico and Chile, have been excluded from the analysis either because of the democratic requirement, or because of their recent access to the international organization and lack of consistent data. The codebook and some descriptive statistics of the main variables can be retrieved in the online appendix.

iv. We did not consider the second ballots that were retaken in Greece in 2012 and 2015, because there could not be any retrospective evaluation of incumbents that had been in place for only a few weeks. We also discarded the 2000 Croatian election, since there was no previously democratically elected government. Some countries had missing fiscal data before 2008, and the elections considered were reduced to 70 .

v. Cyprus, Ireland and Latvia had sequences of contractionary manoeuvres topping a 9 point overall fiscal consolidation.

vi. We report the coefficients of the full models in the online appendix.

vii. As shown in the online appendix, the inclusion of the two extreme cases does not modify the interpretation. Actually, in Estonia, after an expenditure-based manoeuvre, the coalition in government expanded its support, whereas in Ireland, after a tax-based contraction, it topped a record loss of $26.9 \%$ of the votes.

viii. Sometimes it is the reappointment of the same president or prime minister, sometimes the confirmation of his or her party at the head of the cabinet, and sometimes a government is considered to be terminated in case of ideological change of the coalition. In his qualitative assessment, Alesina, Favero and Giavazzi (2019: 183-187) consider a success story the reappointment of David Cameron in 2015, after the Cons-Libdem coalition, in spite of the fact that the parties composing that cabinet lost more than $14 \%$ of the votes compared to 2010 . The same authors deny the possibility of judging the Italian 2013 electoral tsunami after the technocratic Monti cabinet as connected to its economic policies (whereas see Bellucci, 2014). They further consider Rajoy's 2016 fragile minority cabinet as further testimony that fiscal consolidation does not need to be politically fatal, even "after several years of austerity". However, the authors overlook the inconclusive 2015 election, in which the Popular party lost almost $16 \%$ of the votes, and the overall record of a 314-day political stalemate that continued even after the repeated 2016 election, temporarily ended only because of the PSOE internal divisions (Salmon, 2017). Similar concerns could be advanced also for the reconstruction of the Irish and Portuguese cases (De Giorgi and Santana-Pereira, 2016; Marsh and Mikhaylov, 2014). 